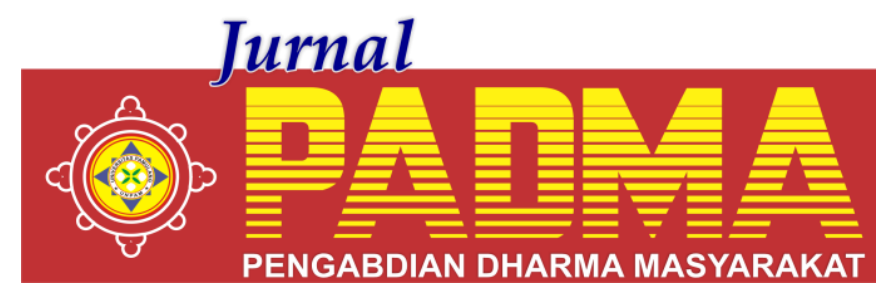

VOLUME 1, NOMOR 3, JULI 2021

\title{
PENYULUHAN PEMANFAATAN MEDIA SOSIAL BAGI PERKEMBANGAN SUMBER DAYA MANUSIA (SDM) PADA MASYARAKAT DESA
}

\author{
${ }^{1}$ Haikal, ${ }^{2}$ Ahmad Ridwan, ${ }^{3}$ Imam Andrianto, ${ }^{4}$ Wahyu Afif, ${ }^{5}$ Rusli, 6*'Denok Sunarsi \\ Universitas Pamulang, Tangerang Selatan, Banten, Indonesia \\ *denoksunarsi@unpam.ac.id
}

\begin{abstract}
Abstrak
Tujuan dari penelitian ini adalah untuk mengetahui dan menganalisis peran media sosial dalam mengembangkan kualitas sumber daya manusia khususnya di desa cidokom bogor, oleh sabab itu media sosial harus di mafaatkan sebaik mungkin agar kulitas sumber daya manusia yang kita miliki meningkat yaitu seperti : Tetap berkomunikasi dengan kolega dan teman, Dapat menemukan teman lama atau kenalan lama kita, Menemukan kandidat untuk pekerjaan, Menemukan Pekerjaan baru, Membangan tampilan pribadi secara online, Bergabung dengan grub yang bermanfaat, Mengembangkan koneksi sosial, Memasarkan produk kita, Memberi kesempatan pada konsumen untuk berintraksi dengan produsen
\end{abstract}

Kata Kunci: Media Sosial

Abstract
purpose of this research is to find out and analyze the role of social media in developing the quality of human resources, especially in the village of Cidokom Bogor, because of that social media must be utilized as best as possible so that the quality of our human resources increases, such as: and friends, Can find our old friends or old acquaintances, Find candidates for jobs, Find new jobs, Develop personal views online, Join useful groups, Develop social connections, Market our products, Give consumers the opportunity to interact with producers

Keywords: Social Media

\section{PENDAHULUAN}

Manajemen merupakan salah satu program studi di Universitas Pamulang. Program studi ini memiliki andil dalam mencetak lulusan yang berkarakter serta mampu bersaing di dalam dunia kerja, serta dapat berperan bagi pembangunan. Pengabdian kepada masyarakat adalah bentuk Kegiatan pengabdian masyarakat merupakan salah satu Tri Dharma PerguruanTinggi Selain Pendidikan dan Penelitian, sesuai undang-Undang RI Nomor 20 Tahun 2003 tentang Sistem Pendidikan Nasional, pada Pasal 20 ayat 2 dinyatakan: "Perguruan Tinggi berkewajiban menyelenggarakan pendidikan, penelitian dan pengabdian masyarakat". Pada Pasal 24 ayat 2 disebutkan:"Perguruan tinggi memiliki otonomi untuk mengelola sendiri lembaganya sebagai pusat penyelenggaraan pendidikan tinggi, penelitian ilmiah, dan pengabdian masyarakat".

Pengabdian kepada masyarakat merupakan pelaksanaan pengamalan ilmu pengetahuan, teknologi dan seni budaya langsung pada masyarakat secara kelembagaan melalui metodologi ilmiah sebagai penyebaran Tri Dharma Perguruan Tinggi serta tanggung jawab yang luhur dalam usaha mengembangkan kemampuan masyarakat, sehingga dapat mempercepat laju pertumbuhan tercapainya tujuan pembangunan nasional.

Media sosial adalah suatu interaksi sosial antara individu dalam berbagi dan bertukar informasi. Media sosial dapat mencakup berbagai ide, pendapat, gagasan dan konten dalam komunitas virtual serta mampu menghadirkan dan mentranslasikan cara berkomunikasi baru dengan teknologi yang sama sekali berbeda dari media tradisional. Perkembangan dunia teknologi yang sudah semakin inovatif di era global telah memberikan dampak langsung kepada masyarakat terutama bagi generasi muda Media sosial dapat diakses dengan mudah melalui smartphone (telepon pintar) kapan saja dan dimana saja oleh pemiliknya. 
Platform media sosial sangat banyak ragamnya. Kemunculan Friendster pada tahun 2002 menjadi terobosan awal di dunia media sosial dengan hampir 1 juta pengguna. Facebook menyusul pada tahun 2006 dan disusul oleh platform - platform media sosial yang lain seperti twitter, path, instagram, dan lain-lain. Hal tersebut membuktikan bahwa media sosial dibutuhkan oleh para pengguna smartphone di era global sekarang ini.

Dampak positif

1. Sebagai media penyimpan informasi

2. Situs jejaring sosial bisa membuat anakanak sampai dewasa lebih bersahabat dan perhatian satu sama lain

3. Media sosial dapat menyambung silaturahmi bagi yang memiliki sanak keluarga yang jauh

4. Mempermudah belanja

5. Dapat sebagai jalan dakwah Dampak negatif

1. Dari media sosial sering terjadi tindakan kejahatan seperti penipuan, pemerkosaan, penculikan dll

2. Susah bersosialisasi dengan sekitar

3. Pergaulan bebas

4. Situs media sosisal akan membuat seseorang lebih mementingkan diri sendiri

5. Media sosial dapat membuat anak-anak dan remaja menjadi lalai dan juga tidak bisa membagi waktu karna terlalu asik dengan dunia maya

Karena itulah media sosial adalah sangat penting untuk kita kuasa di era seakrang ini karena bisa untuk meningkatkan kualitas sumber daya manusia baik itu secara pribadi ataupun kelompok.

\section{METODE}

Dengan menggunakan diskusi kelompok penyuluhan ini di harapkan untuk meningkatkan kualitas sumber daya manusia dalam teknologi khususnya media sosial. Tidak dapat disangkal lagi kehadiran media sosial seperti angin segar bagi kebanyakan orang, terutama mereka yang sangat suka bersosialisasi dengan orang banyak. kehadiran media sosial ini juga sangat bermanfaat untuk membangun dan memperluas jaringan profesional kita di dunia kerja ataupun di dala kehidupan bermasyarakat. Melalui media sosial, kita bisa mendapatkan kontak baru, merekrut karyawan, bahkan mendapatkan pekerjaan baru serta mempromosikan barang dagang kita. Semua itu bisa kita lakukan tanpa harus mengeluarkan biaya yang banyak. Dalam kata lain, media sosial adalah komponen penting dalam memperluas jaringan profesional, meningkatkan kesuksesan karier dan membantu pengembangan karier kita di masa depan.

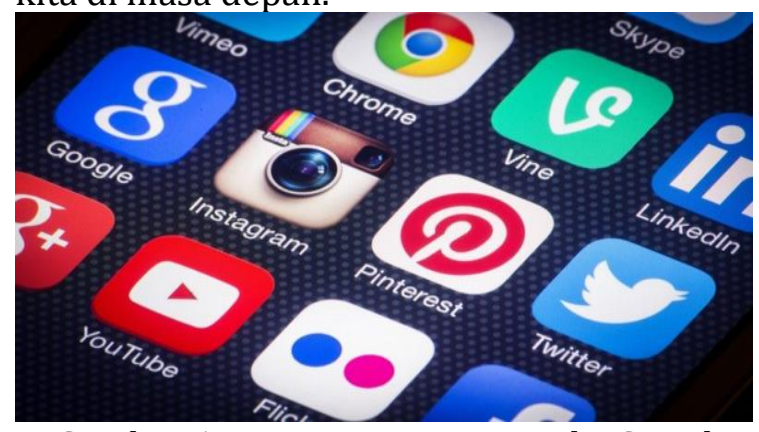

Gambar 1. Macam - Macam Media Sosial Online

\section{HASIL DAN PEMBAHASAN}

Pelaksanaan kegiatan yang akan dilakukan untuk mengatasi permasalahan adalah sebagai berikut (Silvia \& Permana, 2018):

Materi penyuluhan adalah memberitahukan manfaat mendia sosial untuk meningkatkan kualitas Sumber Daya Manusia, salah satu faktor penting untuk meningkatkan kualitas diri kita sebaga Sumber daya manusia adalah mengetahui dengan baik dan benar manfaat media sosial sehingga terbuka pikiran serta tumbuh minat dan motivasi dalam diri mereka untuk meningkatkan kualitas diri Penyuluhan ini disampaikan dalam bentuk ceramah dan tanya jawab kepada peserta. kegiatan Pengabdian Kepada Masyarakat (PKM) di Mushola An-Nur JL SDN Melati RT.03/03, Desa Cidokom, Parung, Cidokom, Kec. Gn. Sindur, Bogor

Berikut adalah pembahsan materi :

1. Tetap berkomunikasi dengan kolega dan teman.

Kira-kira ada berapa banyak kolega atau teman lama yang kita miliki yang masih berinteraksi atau minimalnya memiliki kontak di ponsel, mungkin totalnya bisa dihitung dengan jari saja. Era digital membawa media sosial di tengah-tengah kehidupan kita seperti Facebook dan Twitter yang dapat 
memudahkan kita untuk mencari teman lama, bertegur sapa, bahkan bertemu mereka kembali secara tatap muka, seperti yang biasa kita sebut sebagai reuni. Tidak hanya itu, mereka yang lama hilang kontak dengan kita juga bisa ditemukan di akun LinkedIn, akun media sosial untuk memperluas jaringan profesional di dunia kerja. Mereka yang lama tidak kita temui, bisa saja sekarang sudah menjadi Direktur sebuah perusahaan. Positifnya, kita bisa menambah jaringan dengan kawan lama

2. Dapat menemukan teman lama atau kenalan lama kita.

Sebaliknya, bisa saja beberapa teman lama kita sedang mencari-cari kontak kita sekarang, media sosial memainkan peranannya dalam hal in. Melalui media sosial, mereka bisa menemukan kita dengan mudah. Hanya dengan mengetik nama lengkap atau nama depan seseorang, kita bisa mendapatkan kontak akun mereka di media sosial. Apabila mereka menemukan beberapa nama yang sama, mereka bisa mengeceknya satu per satu dan melihat apakah foto profil yang dipasang sama dengan wajah kita atau tidak.

3. Menemukan kandidat untuk pekerjaan.

Jika kita adalah seorang wirausaha, pebisnis atau pemilik perusahaan? Atau mungkin seorang HRD perusahaan? media sosial telah membantu memudahkan kita untuk bisa mencari kandidat-kandidat berkualitas untuk posisi pekerjaan yang kita tawarkan. Media sosial tidak lagi membuat kita harus memasang iklan lowongan pekerjaan di koran atau majalah. Semuanya bisa diakses dengan jempol kita, dan berbagai lowongan pekerjaan dari berbagai perekrut yang berbedabeda bisa hadir untuk kita pilih. Sebagai contoh, LinkedIn atau Jobstreet, kita bisa menggunakan dua platform tersebut untuk menyeleksi kandidat-kandidat berkualitas yang cocok dengan budaya kerja perusahaan kita atau usaha kita.

4. Menemukan Pekerjaan baru.

Kita tidak perlu bersusah payah mencari pekerjaan dengan berjalan kaki dari satu perusahaan ke perusahaan lainnya. Semua itu sudah tidak berlaku lagi di zaman sekarang. kita hanya perlu duduk manis di depan laptop atau ponsel, dan pergi ke situs pencarian kerja, lalu kita bisa melamar pekerjaan disana dan memenuhi syarat-syarat melamar pekerjaan sesuai informasi lowongan pekerjaan tersebut

5. Membangan tampilan pribadi secara online.

Media sosial sangat membantu kita untuk membangun tampilan pribadi secara online. Di dunia online, kita bisa menampilkan apa keahlian yang kita miliki? Apa yang ingin kita capai? Bagaimana kesan kita di mata rekanrekan kerja dan kerabat kita? Semuanya bisa ditata dengan rapi di media sosial. Positifnya, apabila kita ingin memperluas jaringan profesional, meningkatkan karier untuk bisnis kita atau mencari pekerjaan baru, mereka bisa mencari nama kita dengan mudah di media sosial dan mengetahui rekam digital kita dengan baik.

6. Bergabung dengan grub yang bermanfaat. Media sosial sangat memungkinkan kita untuk membuat grup-grup bermanfaat berdasarkan minat dan profesi kita. Apabila kita suka memasak, kita bisa bergabung dengan grup masak di Facebook. Selain itu, ada juga beberapa komunitas yang mungkin sangat tertarik untuk diikuti seperti, komunitas pembaca buku, komunitas penyuka warna merah, dan lain sebagainya. Disana, kita juga bisa saling berbagi informasi menarik terkait profesi dan minat yang kita geluti. Media sosial membuat kita lebih mudah bertemu dengan orang-orang yang sepemikiran dengan kita, tanpa harus pergi keluar dan mencari teman yang memiliki ketertarikan yang sama.

7. Mengembangkan koneksi sosial.

Media sosial juga membantu kita untuk mengembangkan koneksi sosial dari waktu ke waktu. Tidak sulit untuk mencari teman zaman sekarang, cukup "berselancar" di depan laptop dan membuka media sosial, kita bisa mendapatkan teman sebanyakbanyaknya. kita juga bisa memiliki banyak teman dari berbagai Negara lain Jadi, kita juga bisa mempraktikkan kemampuan bahasa Inggris kita untuk berkomunikasi 
dengan mereka, atau belajar bahasa baru dari mereka. Sudah punya banyak teman, dapat ilmu gratis lagi.

8. Memasarkan produk kita.

Sudah banyak orang mengunakan media sosial sebagai sarana memperluan bisnis yang kita miliki baik itu usaha pribadi, kelompok mau pun re-seller semua bisa di pasarkan di media sosial, bahkan seperti Facebook dan instragram memiliki pemawaran sendiri untuk orang-orang yang meninginkan produknya di pasarkan otomais oleh facebook dan instagram.

9. Memberi kesempatan pada konsumen untuk berintraksi dengan produsen.

Kritik dan saran tidak lagi hanya dapat disampaikan melalui telepon atau email dari konsumen kepada produsen tersebut. Kehadiran media sosial memudahkan interaksi antara produsen dan konsumennya. Apabila konsumen ingin memberikan beberapa kritik dan saran, mereka bisa langsung pergi ke laman twitter, Facebook atau Instagram, untuk menyampaikan aspirasi mereka. Bahkan, respons yang diberikan dari produsen juga sangat cepat. Begitu juga dengan produsen, jika mereka memiliki promo atau hadiah untuk para konsumen setianya, dengan mudah mereka bisa mempostingnya di media sosial. Sekarang interaksi antara keduanya benar-benar menjadi sangat mudah.

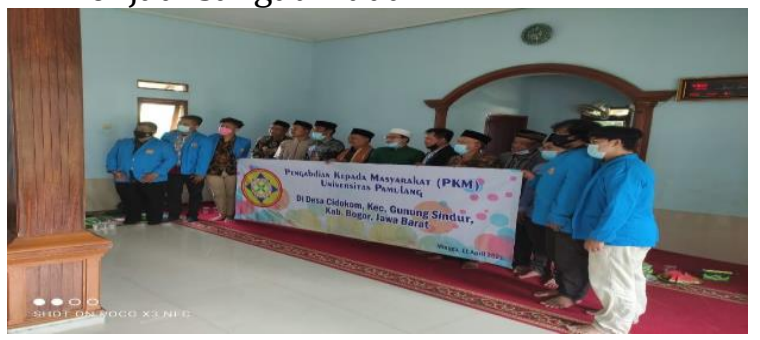

Gambar 2. Foto Bersama PKM

Dari pembahasan di atas, dapat di simpulkan bahwa media sosial dapat meningkatkan kualitas sumber daya manusia dengan benar kalau kita sebagai pengguna mengunakan media sosial dengan baik dan benar dan tidak melakukan kegiatan di luar hukum dan norma agama.

\section{PENUTUP}

Acara kegiatan pengabdian kepada masyarakat ini dilaksanakan selama 5 hari, yaitu sebagai berikut. Hari pertama dan kedua adalah meminta izin dari universitas dan camat dan $\mathrm{dkm}$ mushola cidokom, hari ketiga dan keempat adalah suvei tempat yang akan di pakai dalam pelaksanaan pengabdiaan kepada masyarakat, hari kelima adalah kegiatan penyuluhan mengenai pemanfaatan media sosial bagi perkembangan Sumber daya manusia pada masyarakat desa

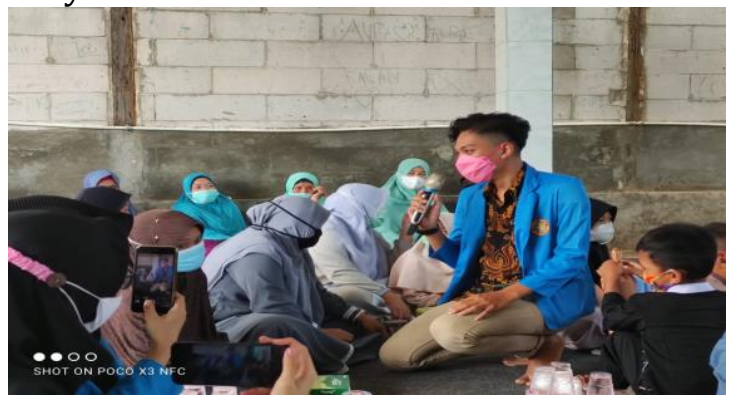

Gambar 3. Penyuluhan Dari Narasumber Terhadap Peserta PKM

\section{DAFTAR PUSTAKA}

Ghozali, Imam. 2000. Aplikasi Analisis Multivariate dengan SPSS. Semarang: Universitas Diponegoro.

Marsal, A,. Hidayati, F (2018). Pengaruh penggunaan media sosial terhadap kinerja pegawai di lingkungan UIN Suka Riau. Jurnal Ilmiah Rekayasa dan Manajemen Sistem Informasi, Vol 4(1), 91-98

Romdonny, J,. Rosmadi, M,. (2018). peran media sosial dalam mendukung pemasaran produk organisai bisnis. Ikraith Ekonomica Vol 1(2), 25-30

Sunarsi, D., Akbar, I. R., Rozi, A., Khoiri, A., \& Salam, R. (2021). The Influence of Motivation and Work Discipline on Employee Performance at the Yogyakarta Tourism Service. Prosiding ICoGEMT, 1(1), 1-7.

Nurjaya, N., Sunarsi, D., Effendy, A. A., Teriyan, A., \& Gunartin, G. (2021). Pengaruh Etos Kerja Dan Disiplin Kerja Terhadap Kinerja Pegawai Pada Dinas Kehutanan Dan Perkebunan Kota Bogor. JENIUS (Jurnal Ilmiah Manajemen Sumber Daya Manusia), 4(2), 172-184. 